\title{
The prevention and punishment of corruption in the italian legislation
}

\author{
La prevenzione e la repressione della \\ corruzione nell'ordinamento giuridico italiano
}

Federico C. La Vattiata ${ }^{1}$

Table of Contents: 1. Introduction. 2. The Criminal Code provisions in force. 3 . The liability of the legal persons. 4. The National Anti-Corruption Authority (Autorità Nazionale Anticorruzione, ANAC). 5. The Directive (EU) 2017/1371. 6. Conclusion.

Abstract: This article aims to provide an overview of how the Italian legislation deals with corruption. This starts with an analysis of the crimes provided for in the Criminal Code. In this regard, the three major offences are described that concern the phenomenon which is usually referred to as corruption (alias bribery) in comparative law: concussione, corruzione, and induzione indebita a dare o promettere utilità. The comparative analysis demonstrates that their distinction is not common.

Secondly, these crimes are grounds for establishing the (substantially criminal) liability of

1 Ph.D. Student in Compared and European Legal Studies (Criminal Law) University of Trento (Italy) 
the legal persons, whose regulation is provided for in the Decreto Legislativo n. 231/2001.

Thirdly, the mission and the activity of the National Anti-Corruption Authority is described.

Finally, given that the Italian Republic is a Member State of the European Union, the Directive (EU) 2017/1371 on the fight against fraud to the Union's financial interests by means of criminal law is depicted. Indeed, among the crimes within the scope of the Directive, there are the figures of active and passive corruption.

Keywords: Corruption - Criminal Law - Italian Legislation - Legal Persons - European Union - PFI

Riassunto: Il contributo offre una panoramica degli strumenti adottati dal legislatore italiano al fine di contrastare il fenomeno della corruzione.

A tal proposito, vengono in primo luogo analizzate le figurae criminis tipizzate all'interno del codice penale. Da questo punto di vista, l'autore propone una descrizione, pur sintetica, delle tre differenti fattispecie delittuose che rilevano ai fini della trattazione del fenomeno corruttivo, la cui distinzione, a livello comparatistico, non conosce larga diffusione: la concussione, la corruzione e l'induzione indebita a dare o promettere utilità.

In secondo luogo, viene posto in luce come tali fattispecie rientrino tra i reati-presupposto della responsabilità (sostanzialmente penale) degli enti giuridici, la cui disciplina è stata introdotta solo nel 2001 mediante il decreto legislativo n. 231.

In terzo luogo, viene offerta una sintetica descrizione della mission dell'attività dell'Autorità Nazionale Anticorruzione, recentemente istituita.

In quarto luogo, il contributo offre alcuni cenni in merito all'adesione dell'Italia all'Unione europea, funzionali alla trattazione delle strategie adottate a 
livello sovranazionale al fine di contrastare le frodi che ledono gli interessi finanziari dell'Unione. Tra le condotte lesive e rientranti nel campo di applicazione della recente Direttiva c.d. PIF vanno rammentate la corruzione attiva e passiva.

Parole chiave: Corruzione - Diritto penale Ordinamento italiano - Persone giuridiche - Unione Europea - PIF

\section{Introduction}

The Italian Criminal Code (still in force) was adopted in 1930.

However, the legislation on corruption has been amended several times in the years following its introduction.

The attention payed by the Italian lawmakers to the crime of corruption intensified after the scandal, journalistically known as Tangentopoli or Mani Pulite, that involved the main political parties in the early $90 \mathrm{~s}$.

\section{The Criminal Code provisions in force}

The Italian legislation provides for three crimes, whose distinction, clear in theory, can be (and has been) difficult in practice: within the II Book (dei delitti in particolare) II Title (dei delitti contro la Pubblica Amministrazione), besides the crimes of corruption in the strict sense (corruzione: articles 318 - 322), there are the so-called concussione (article 317) and induzione indebita a dare o promettere utilità (art. 319-quater).

These offences will be analysed, paying attention to their structural elements. 


\subsection{The perpetrators}

The crimes contro la Pubblica Amministrazione need that the perpetrators hold a special position.

In particular, the aforementioned offences need that the perpetrator, as appropriate, holds the position of pubblico ufficiale (public official) or incaricato di pubblico servizio (subject in charge of public service), whose definitions are provided for in articles 357 and 358 of the Criminal Code (hereinafter the Code).

Pursuant to article 357, «for the purposes of criminal law», pubblici ufficiali are «those exercising a public legislative, judicial or administrative function». Moreover, the provision states that «the administrative function is public when it is regulated by public law norms and authoritative acts, and characterised by the fact that it concerns the formation and the expression of the public administration's will, or by the implementation of the public administration's will by means of powers either authoritative or of certification».

Instead, pursuant to article 358, «for the purposes of criminal law», incaricati di un pubblico servizio are «those that, in any capacity, are on public duty», whereas public duty «means an activity regulated in the same way of a public function, but characterised by the lack of the related powers, and except the exercise of simple tasks of order and merely material work».

\subsection{Concussione}

Pursuant to article 317 of the Code, «if a pubblico ufficiale or an incaricato di un pubblico servizio, abusing his/her own position or powers, forces someone to illegitimately give or promise him/her or another third person, money or a different benefit, he/she is punished with imprisonment 
from six to twelve years».

Concussione is the most serious crime committed by a public subject (hereinafter intraneus) against the Public Administration.

The provision aims at avoiding that the perpetrator manipulates his/her own position with intent to stress the private subject's (hereinafter extraneus) freedom of choice ${ }^{2}$.

This offence is a special form of extorsion. The speciality relates to the crime's methods of commission, and in the intensity of the psychological coercion ${ }^{3}$.

As for the perpetrators, the crime can be committed either by a pubblico ufficiale or by an incaricato di pubblico servizio.

According to the traditional doctrine, the legal interest (hereinafter also referred to as legal good or Rechtsgut) protected by article 317 is the intraneus' duty of probity, fidelity and fairness ${ }^{4}$.

Instead, according to the modern doctrine, the protected interest is the proper operation of the Public Administration, from the point of view of efficiency and impartiality, in the light of article $97^{5}$ of the Constitution ${ }^{6}$.

2 G. Fiandaca, E. Musco, Diritto Penale. Parte speciale. Volume 1, Zanichelli, Bologna, 2012, p. 208.

3 M. N. MASUlLo, I delitti di concussione e di induzione indebita a dare o promettere utilità, in S. Fiore, G. Amarell (edited by), I delitti dei pubblici ufficiali contro la pubblica amministrazione, Utet, Milano, 2018, p. 91.

4 F. Antolisei, Manuale di diritto penale. Parte speciale II, Giuffrè, Milano, 2016, p. 405.

5 Article 97 Cost.: «Public offices are organised according to the provisions of law, so as to ensure the efficiency and impartiality of administration. The regulations of the offices lay down the areas of competence, the duties and the responsibilities of the officials. Employment in public administration is accessed through competitive examinations, except in the cases established by law».

6 G. Fiandaca, E. Musco, Ibidem. 
In particular, impartiality would be prejudiced by the fact that the perpetrator manipulates (for private purposes) the rules concerning the proper exercise of public powers ${ }^{7}$.

Concussione is a crime characterised by the cooperation of the victim (the extraneus).

The central element is the coercitive conduct of the intraneus. It does have two structural functions: on the one hand, it is the effect of certain behavioural methods (i.e. the abuse of the position or the abuse of the powers); and on the other, it causes the following victim's conduct, who decides, by virtue of the coercion itself, to give or promise money or some other benefit ${ }^{8}$.

Abuse of the powers (the so-called objective abuse) means the exercise of the public powers not compliant with the rules of efficiency and impartiality that the Constitution sets with regard to the public offices.

Abuse of the position (the so-called subjective abuse), instead, means that the intraneus acts in a way that makes the victim feel the superiority of his/ her position, in contexts where there is no need to point it out ${ }^{9}$.

According to the jurisprudence, if the intraneus threatens to do something legal, but with intent to get something undue from the extraneus, this can fulfil the actus reus ${ }^{10}$.

The mental element is the so-called dolus, i.e. intent and knowledge with regard to all the structural elements of the crime.

The crime of concussione is fulfilled when the extraneus transfers (or promises) money or another benefit to the intraneus.

7 M. N. Masullo, Ivi, p. 95.

8 M. N. Masullo, Ivi, p. 96.

9 M. N. Masullo, Ivi, p. 98.

10 Corte Suprema di Cassazione, Sezioni Unite, judgement n. 12228 (24.10.2014). 
The fact that article 317 refers alternatively either to the transfer or to the promise is due to the aim of anticipating the crime's fulfilment at an early stage, i.e. previous to the transfer, and even if the transfer does not occur. However, this has implied problems, i.e. clarifying when the crime is fulfilled in two cases: a) if the transfer occurs after the promise; and b) if the transfer is made in instalments ${ }^{11}$.

Indeed, this question is common to the crimes of corruzione and induzione indebita a dare o promettere utilità.

According to the prevailing jurisprudence, all these crimes do have a double structure, i.e. the tempus commissi delicti coincides with: a) the transfer's moment, if this is made after the promise; $b$ ) the promise's moment, if there is no transfer after the promise. Moreover, in the first case, if a transfer is made in instalments, the tempus commissi delicti is the moment of the last instalment ${ }^{12}$.

\subsection{Corruzione}

The Criminal Code provides for a complex regulation about corruption in articles from 318 to 322. Actually, one can identify several offences: corruzione per l'esercizio della funzione; corruzione per un atto contrario ai doveri d'ufficio; and the special figure of corruzione in atti giudiziari.

As for the figure of corruzione per l'esercizio della funzione, pursuant to article 318: «If the pubblico ufficiale illegitimately receives money or another benefit, or accepts the promise of money or another benefit, in favour either of himself/ herself or of a third person, in exchange for exercising his / her function, he/she is punished with imprisonment from three to eight years».

11 M. N. Masullo, Ivi, p. 117.

12 Ibidem. 
The perpetrators are:

- the intraneus, namely the pubblico ufficiale and (in the light of article 320) the incaricato di pubblico servizio;

- $\quad$ and the extraneus, in the light of article 321.

The legal interest protected by the provisions concerning the crimes of corruzione is controversial.

In this regard there are two opinions.

According to the first doctrine, the protected interest is the same in all the crimes of corruzione, i.e. the duty of fidelity, probity, correctness, loyalty, etc. of the intraneus.

According to the second one, instead the Rechtsgut is different in the various figures.

However with regard to the crime provided for in article 318 the protected interest is the efficiency of the Public Administration.

As for the intraneus, the actus reus consists in receiving an illicit remuneration (money or another benefit) or accepting the promise of it (regardless of the fact that the transfer or the promise is in favour either of the intraneus himself/herself or of a third person).

As for the extraneus, it consists in paying or promising the illicit remuneration itself.

The mens rea consists in the so-called dolo, that is intent and knowledge of:

- receiving (or accepting the promise of) the illicit remuneration, from the point of view of the intraneus;

- transferring or promising the remuneration, from the point of view of the extraneus.

The crime is fulfilled when (and where) the corruptive agreement between the intraneus and the extraneus is made. 
The figure of corruzione per un atto contrario ai doveri $d^{\prime}$ ufficio is provided for in article 319, pursuant to which: «If the pubblico ufficiale receives money or another benefit, or accepts the promise of money or another benefit, in favour either of himself/herself or of a third person, in exchange for (with the intent of) omitting or delaying (or for having omitted or delayed) the adoption of an act of his/her office, or for adopting (or having adopted) an act contrary to his/ her official duties, is punished with imprisonment from six to ten years».

Moreover, article 319-bis provides for some aggravating factors: «The sanction is aggravated if the conduct provided for in article 319 refers to: the assignment of public offices or remunerations; the making of an agreement in which the Administration, to whom the pubblico ufficiale belongs, is interested; or the payment or repayment of taxes».

The perpetrators are the same of the crime of corruzione per l'esercizio della funzione.

As for the Rechtsgut, according to an opinion prevailing in the past, it should have been the Administration's prestige ${ }^{13}$.

Recently, instead, it has been pointed out that article 319 protects the efficiency and impartiality of the Administration 14.

The actus reus consists in:

- receiving (or accepting the promise of) money or another benefit (regardless of the fact that the transfer or the promise is in favour either of the intraneus himself/herself or of a third person), as

13 F. BRICOLA, Tutela penale della pubblica amministrazione e principi costituzionali, in Temi, 1968, p. 141.

14 G. Fiandaca, E. Musco, Ivi, p. 226. 
for the intraneus;

- transferring or promising money or another benefit, as for the extraneus.

According to the prevailing opinion, a remunerational link between these two conducts is an essential element of the crime.

Thus, there should be proportionality between the two performances. As a result, some cases are not considered relevant, such as small donations and unbalanced performances.

The notion of another benefit is controversial. There are three opinions:

According to the first doctrine, another benefit is something thanks to which the intraneus takes an advantage.

According to the second one, it consists in patrimonial assets, at least characterised by the element of materiality.

According to the third one, what is essential is the fact that the benefit can be considered as a remuneration ${ }^{15}$.

The notion of contrariness to the official duties is also controversial. It depends on the interpretative choice concerning the protected interest. As a matter of fact, an act contrary to the official duties can consists in: either an act that violates on the one hand the general duties of fidelity, correctness and honesty, and on the other the specific duties that relates to a specific deal; or an act contrary to law and regulations.

Thus, if one considers the efficiency and impartiality of the Administration as protected interests, the act is considered in compliance with or contrary to the official duties with regard to certain official duties, in the light of the

15 G. Fiandaca, E. Musco, Ivi, p. 227 s. 
administrative law norms that regulate the office's activity ${ }^{16}$.

The mens rea is the dolo. Moreover, the dolo is specific (i.e. the so-called specific intent), that is the specific intention, required as a constitutive element of the crime, which demands that the perpetrator clearly seeks to realise a further aim: the omission or delay in adopting an act of the office, or the adoption of an act contrary to the official duties.

In other words, the specific intent is formulated according to a technique appearing in several national criminal systems: that is, the identification of a particular surplus of the purpose as compared to the actus reus, that is the common object of the general standard of intent and knowledge. For example, besides the Italian notion of the aforementioned dolo specifico, we can cite the Germanic figure of the socalled Absichtsdelikte (intentional crimes). Actually, also in common law systems - which are historically less sensitive to the dogmatic elaboration of this category - more attention is gradually being paid (at least at the doctrinal and jurisprudential level) to the crimes characterised by a weighty intentional element, in the sense of intent to commit further acts as compared to the actus reus.

The modern doctrines, both Continental and AngloSaxon, reject a purely psychological understanding of the specific/further intent (in the sense of a mens rea's subelement). It is instead theorised a central role of the intent within the objective element of the crime.

However, as for the way in which such a specific intent links the protected interests of a crime's provision, pursuant to a rigorous approach, the agent, on the one hand, must disclose his/her intent to realise the further result, and, on the other hand, he/she must commit a base-fact suitable to fulfil the forbidden future result.

16 G. Fiandaca, E. Musco, Ivi, p. 228 s. 
The link that must connect the base-fact to the further event is subjective and teleological (instead of physicnaturalistic). Indeed, the second term of this relationship is only the purpose (the psychic cause) that brings about the agent's conduct, and not a naturalistic event etiologically linked to the latter. Since this further element (as previously expressed) concerns the objective element, its validation needs the proof of the finalistic nexus between the agent's conduct and its ultimate purpose in the context of the ascertainment of the actus reus, albeit by means of the further elements as compared to the (materially considered) conduct.

The crime of corruzione per un atto contrario ai doveri $d^{\prime} u f f i c i o$ is fulfilled when and where the intraneus receives or accepts the promise of money or another benefit.

The special figure of corruzione in atti giudiziari is provided for in article 319-ter, pursuant to which: «If the facts provided for in articles 318 and 319 are committed with the intent to favour or damage the interests of a part in a civil, administrative or criminal trial, the sanction is the imprisonment from six to twelve years». Furthermore, «if this conduct causes someone's unjust conviction to imprisonment not exceeding five years, the sanction is the imprisonment from six to fourteen years; if it causes someone's unjust conviction to imprisonment exceeding five years or a life sentence, the sanction is the imprisonment from eight to twenty years».

According to GIOvanni Fiandaca and EnZO Musco, this offence is more serious than the ones provided for in articles 318 and 319 of the Criminal Code ${ }^{17}$.

The mental element is the specific intent: the conduct needs to be committed «with the intent to favour or damage the interests of a part in a civil, administrative or criminal

17 G. Fiandaca, E. Musco, Ivi, p. 236. 
trial». In this regard, we can refer to the abovementioned observations concerning the dolo specifico from a general point of view.

Paragraph 2 of article 319-quater provides for two aggravating factors, consisting in the fact that the conduct causes someone's unjust conviction to imprisonment exceeding or not exceeding five years. A conviction is considered unjust even also if someone is guilty, but he/she would have been convicted to a milder sentence without the perpetrator's conduct.

Finally, pursuant to article 322, also inciting the commission of the crimes provided for in articles 318 and 319 is punished, although by means of a sanction reduced by one third.

It should be pointed out that in the Italian legal system, in the light of the general rule provided for in article 115 of the Criminal Code, inciting the commission of a crime is generally not punished, when, in spite of the incitement itself, the offence is not committed. However, this rule is valid «unless otherwise provided by the law» solely, as in the case provided for in article 322.

\subsection{Induzione indebita a dare o promettere utilità}

The figure of induzione indebita a dare o promettere utilità is provided for in article 319-quarter according to which: "Unless the fact is a more serious crime, if the pubblico ufficiale or the incaricato di pubblico servizio induces someone to transfer or promise money or another benefit either to himself/herself or to a third person, abusing his/her own position or powers, is punished with imprisonment from six to ten years». Anyhow, «in the abovementioned cases, whoever transfers or promises money or another benefit is 
punished with imprisonment for up to three years».

The perpetrators are:

- The pubblico ufficiale or the incaricato di pubblico servizio;

- And the extraneus, although he/she is punished with a less sever sanction.

The protected interests are the efficiency and the impartiality of the Administration.

The actus reus:

- as for the intraneus, consists in inducing someone to pay or promise an illicit performance;

- as for the extraneus, consists in paying or promising the illicit performance.

\subsection{The problematic distinction between the crimes of concussione, corruzione and induzione indebita a dare o promettere utilità}

As already mentioned, in the Italian legal system these are three separate crimes, whose differences may be not clear, but can be distinguished.

Indeed, the framework is even more complicated, since before 2012 (when article 319-quater has been introduced), the Criminal Code contained a provision concerning the crime of concussione (old article 317) which referred both to conducts of coercion and induction.

In 2012 the Parliament approved a reform (the so-called Legge Severino n. 190): the conduct of induction has been separated from article 317 and inserted in a new provision, namely article 319-quater. 
There are relevant differences, since in the light of article 319-quater the extraneus is now punished, although with a milder sanction.

Thus, the jurisprudence had to solve intertemporal questions.

At first, there were three tendencies within the Corte di Cassazione (a.k.a. Suprema Corte, hereinafter SC or Court).

According to the first, the distinctive element would have been the different prevaricator pressure by the intraneus: if the extraneus' self-determination had been seriously jeopardized, it would have been concussione; in cases of milder pressure, instead, it would have been induzione indebita ${ }^{18}$.

According to the second, the distinctive element would have been the object presented by the intraneus to the extraneus: unjust and contra ius damage in the crime of concussione; just and secundum ius damage (i.e. unfavourable consequences arising from the application of law) in the crime of induzione indebita ${ }^{19}$.

According to the third, a synthesis of the previous tendencies would have been needed ${ }^{20}$.

Given the difficulties in clarifying the difference between the crimes, the question was submitted to the Sezioni Unite (i.e. a sort of Great Chamber) of the Court.

Therefore, the SC solved the question and set an important precedent, namely Maldera ${ }^{21}$.

According to the Sezioni Unite, all the previous tendencies were wrong: the first criterion would have caused problems due to the fact that it requires difficult psychological

18 Corte Suprema di Cassazione, Sezione IV, judgement n. 8695 (4.12.2012).

19 Corte Suprema di Cassazione, Sezione IV, judgement n. 3251 (3.12.2012).

20 Corte Suprema di Cassazione, Sezione IV, judgement n. 11754 (11.2.2013).

21 Corte Suprema di Cassazione, Sezioni Unite, judgement n. 12228 (24.10.2014). 
investigations; the second would have not mirrored the different seriousness of the crimes; the third would have shared the previous tendencies' flaws.

Among the reasons that inspired the reform in 2012 there was the aim to reduce the cases of impunity of the extraneus when he/she decides to pay a bribe. The achievement of this aim was pushed for by soft-law sources, such as the GRECO (Group of States against Corruption) report, concerning the matter of international corruption.

According to the Court, the crime of concussione would jeopardize not only the efficiency and the impartiality of the Administration, but also the victim's interests, i.e. his/her self-determination and his/her assets ${ }^{22}$.

As for this offence, the SC affirms that the conduct of coercion is "a "heterodetermination" of others' will, in the sense that someone is obliged to do something that otherwise would not have been done, or to refrain from doing something that would otherwise have been done». It can be committed by means of either duress or threat.

Threat means that the intraneus presents an unjust and contra ius damage to the extraneus, namely a damage contrary to law and jeopardizing a victim's personal or patrimonial interest ${ }^{23}$.

The extraneus must not achieve the purpose of illicit advantages; differently, he/she could not be considered as a victim ${ }^{24}$.

According to the Court, the so-called metus publicae potestatis (i.e. the extraneus's fear of the public potestas in the light of the intraneus' higher position) is «not a structural

22 M. N. Masullo, Ivi, p. 104.

23 Corte Suprema di Cassazione, Sezioni Unite, judgment n. 12228 (24.10.2014), $\S 13.4$.

24 Ibidem, § 13.5. 
element of the crime; it represents the victim's psychological awe, the other side of the abuse of position/ powers.

The metus expresses the strong conditioning of the victim's self-determination. Thus, he/she, being afraid of the damage threatened by the intraneus, surrenders to the threat ${ }^{25}$.

The conduct of induction, therefore, does play a residual role in the Court's reasoning. Its scope coincides with the cases that are not part of the concussione's scope, namely those intraneus' conducts, also abusive and criminally relevant, that are not expressed by means of duress or threat of an unjust damage. These conducts do not force the extraneus to choose between two unjust damages ${ }^{26}$.

In conclusion, the Court affirms that the difference between the crime of concussione and the crime of induzione indebita can be expressed with the dichotomous concept of threat/non-threat ${ }^{27}$.

Moreover, the Court investigates the distinction between the crime of induzione indebita and the crime of corruzione. The first one is a sort of middle ground between concussione and corruzione. The distinction consists in the different way by which the intraneus achieves the illicit advantage: if there is a freely and knowingly made agreement between two persons who aim at a common illicit purpose in a context of synallagmatic equality, the crime is corruzione; instead, as already explained, if there is the extraneus' psychological subjection, the crime is induzione indebita ${ }^{28}$.

25 Ibidem, § 13.6 .

26 Ibidem, § 14.3.

27 Ibidem, § 14.4 .

28 Ibidem, § 24.2 . 


\section{The liability of the legal persons}

In the Italian law system, the criminal liability has been traditionally considered as referable to natural persons solely, in the light of the formula societas delinquere et puniri non potest (i.e. companies cannot commit a crime and be punished).

However, in 2001 the Executive branch, authorised by the Parliament, approved the Decreto Legislativo $\mathrm{n}$. 231 (hereinafter the Decree), thus introducing for the first time a legislation about the (formally administrative, but substantially criminal) responsibility of the legal persons (hereinafter entities).

The grounds for recognizing an entity as responsible for a crime are the following:

a) Pursuant to article 1 of the Decree, the entities' liability depends on unlawful administrative acts relating to crimes. The provisions set out therein apply to corporate entities, companies and associations including those which are not corporate-bodies. They do not apply to the State, to territorial public bodies, to other noneconomic public bodies or to bodies performing constitutionally significant functions.

b) Someone (a natural person) linked to the entity (a senior manager ${ }^{29}$ or an employee ${ }^{30}$ ) must commit one of the offences listed in articles from

29 I.e. persons holding a representation, administration and management role in the entity or in one of its organisational units, provided with financial and functional independence, as well as by persons who, de facto or otherwise, manage and control the entity.

30 I.e. persons subject to the direction and supervision of the Senior Management. 
24 to 25 -duodecies. Among these crimes, there are: concussione; corruzione; and induzione indebita a dare o promettere utilità.

c) There must be an objective link between the entity and the commission of the crime. Namely, the crime must be committed by the aforementioned persons «in the interest or for the benefit of the company» (article 5, paragraph 1 of the Decree): interest exists when the author of the crime has acted with the intent to help the entity, regardless of whether the objective has been reached; benefit exists when the entity has drawn, or could have drawn, a positive result from the crime, not necessarily of an economic nature. However, the entity is not liable in cases where the senior management or subordinate persons have acted «in their own exclusive interest or in the interest of third parties» (see article 5, paragraph 2 of the Decree).

From the point of view of the mens rea, the Decree has introduced a paradigm inspired to the US compliance programs.

If the crime is committed by a senior manager (see article 6 of the Decree), the entity is not liable if it can demonstrate that: 1) the senior executive organ adopted and efficiently enacted, prior to the commission of the crime, organizational and management models which are capable of preventing crimes of the type occurring; 2) the task of overseeing such operations and updating the models has been delegated to an organisation (so-called Organismo di Vigilanza, hereinafter $O d V$ ) within the entity having the powers of initiative and control; 3) the natural persons committed the crime fraudulently evading the models; and 4) there has been no omission or insufficient oversight by the OdV. 
If the crime is committed by an employee (see article 7 of the Decree), the entity is liable only when the commission of the crime is made possible by means of noncompliance with the directive or oversight requirements. Nevertheless, noncompliance with the directive or oversight requirements is excluded if the entity, prior to the commission of the crime, adopted and efficiently implemented an organisational, management and control model which is capable of preventing crimes of the type occurring.

When all these requirements are ascertained, there can be two different (and independent, pursuant to article 8 of the Decree) liabilities: one of the natural person, and one of the entity to which he/she belongs.

\section{The National Anti-Corruption Authority (Autorità Nazionale Anticorruzione, ANAC)}

In 2014 the Autorità Nazionale Anticorruzione (hereinafter $A N A C)$ has been established. It is an independent authority that is «tasked with the analyses of the causes of corruption and with the drafting of the anticorruption strategy, through regulatory and supervising functions. Regarding these functions, the law assigns to ANAC the power to monitor, request the exhibition of documents, and the adoption of acts or the removal of acts and behaviours» contrary to the law and transparency rules. Moreover, "ANAC provides advice to the public administrations on the compliance of public employees with the code of conduct; establishes guidelines and standards for codes of conduct in specific administrative areas; reports annually to the Parliament on anticorruption activities, criminality in public entities and the effectiveness of the adopted strategy» ${ }^{31}$.

31 See http://www.anticorruzione.it/portal/public/classic/MenuServizio/ 
As for the area of transparency (regulated by the Decreto Legislativo n. 33/2013), «the Authority can impose pecuniary sanctions for the violation of the obligation of data publication» ${ }^{32}$.

Also, ANAC is «is tasked with the interpretation of the legal framework on the "ineligibility and incompatibility of positions in the public administration", as well as the supervision on the correct enforcement of the pertinent legislation» ${ }^{33}$.

Pursuant to article 213 of the so-called Code of Public Contracts, i.e. Decreto Legislativo n. 50/2016, ANAC is the «responsible entity for the supervision and regulation of public contracts, in order to ensure compliance with the principles of transparency, legitimacy and competition of the operators in the public procurement market and prevent corruption. Thus, the whole strategy for corruption prevention is concentrated in one single institution. The Authority achieves its goals in the area of public procurement through regulation, advisory in order to prevent disputes - , and supervision function, along with inspection and sanctioning powers. These competences are completed by an important monitoring activity through the collection of data on tenders and on the companies operating in the sector» ${ }^{34}$.

\section{The Directive (EU) $2017 / 1371$}

The Italian Constitution entered into force in 1948. Within it some provisions allow the Italian law to open itself up to supranational and international sources of law. In other

ENG/Ourmandate.

32 Ibidem.

33 Ibidem.

34 Ibidem. 
words, pursuant to articles $10^{35}, 11^{36}$ and 117 paragraph 1 ${ }^{37}$ the Italian Republic has been able to become Member of the Organization of the United Nations, the Council of Europe, and the European Union.

During the years, the integration within the European Union has meant a great development for European citizens, first of all in the sector of the protection of rights and freedoms, thus creating a unique area of freedom, security and justice (the so-called AFSJ) ${ }^{38}$. However, this has also allowed the supra-nationalisation of crime, i.e. criminal conducts have progressively assumed a supranational character. The sector of the so-called white-collar crimes has been involved by this phenomenon. Among these figurae criminis the ones concerning corruption (in general) are undoubtedly relevant. Recently, the European Parliament and the Council have approved the Directive n. 2017/1371 on the fight against fraud to the Union's financial interests by means of criminal law.

During the preparatory work, the question regarding the legal basis for adopting the Directive came to light.

35 Art. 10 Cost.: «The Italian legal system conforms to the generally recognized principles of international law. The legal status of foreigners is regulated by law in conformity with international provisions and treaties. A foreigner who, in his home country, is denied the actual exercise of the democratic freedoms guaranteed by the Italian constitution shall be entitled to the right of asylum under the conditions established by law. A foreigner may not be extradited for a political offence».

36 Art. 11 Cost.: « Italy rejects war as an instrument of aggression against the freedom of other peoples and as a means for the settlement of international disputes. Italy agrees, on conditions of equality with other States, to the limitations of sovereignty that may be necessary to a world order ensuring peace and justice among the Nations. Italy promotes and encourages international organizations furthering such aims».

37 Art. 117.1 Cost.: «Legislative powers shall be vested in the State and the Regions in compliance with the Constitution and with the constraints deriving from EU legislation and international obligations».

38 It can also be pointed out that a real European criminal law has been created (in this regard, see G. GRASSO, Introduzione: Diritto penale ed integrazione europea, in G. Grasso, R. Sicurella (edited by), Lezioni di diritto penale europeo, Giuffrè, Milano, 2007, p. 6). 
Among the provisions that can protect the Union's financial interests, there are, on the one hand, article 325 of the Treaty on the Functioning of the European Union (hereinafterTFEU) ${ }^{39}$ and, on the other, article 83.2 TFEU ${ }^{40}$. Helmut Satzger had even affirmed that article $86^{41}$ could

39 Art. 325 TFEU: «1. The Union and the Member States shall counter fraud and any other illegal activities affecting the financial interests of the Union through measures to be taken in accordance with this Article, which shall act as a deterrent and be such as to afford effective protection in the Member States, and in all the Union's institutions, bodies, offices and agencies.

2. Member States shall take the same measures to counter fraud affecting the financial interests of the Union as they take to counter fraud affecting their own financial interests.

3. Without prejudice to other provisions of the Treaties, the Member States shall coordinate their action aimed at protecting the financial interests of the Union against fraud. To this end they shall organise, together with the Commission, close and regular cooperation between the competent authorities.

4. The European Parliament and the Council, acting in accordance with the ordinary legislative procedure, after consulting the Court of Auditors, shall adopt the necessary measures in the fields of the prevention of and fight against fraud affecting the financial interests of the Union with a view to affording effective and equivalent protection in the Member States and in all the Union's institutions, bodies, offices and agencies. Ù

5. The Commission, in cooperation with Member States, shall each year submit to the European Parliament and to the Council a report on the measures taken for the implementation of this Article».

40 Art. 83.2 TFEU: «If the approximation of criminal laws and regulations of the Member States proves essential to ensure the effective implementation of a Union policy in an area which has been subject to harmonisation measures, directives may establish minimum rules with regard to the definition of criminal offences and sanctions in the area concerned. Such directives shall be adopted by the same ordinary or special legislative procedure as was followed for the adoption of the harmonisation measures in question, without prejudice to Article 76».

41 Art. 86 TFEU: «1. In order to combat crimes affecting the financial interests of the Union, the Council, by means of regulations adopted in accordance with a special legislative procedure, may establish a European Public Prosecutor's Office from Eurojust. The Council shall act unanimously after obtaining the consent of the European Parliament. In the absence of unanimity in the Council, a group of at least nine Member States may request that the draft regulation be referred to the European Council. In that case, the procedure in the Council shall be suspended. After discussion, and in case of a consensus, the European Council shall, within four months of this 
have been a valid basis: the provision would have allowed the approval of a regulation instead of a directive ${ }^{42}$. However, as affirmed by GIOVANNI GRASSO, the Union does not have a full competence in the field of criminal law, given that within the Treaties there is no provision authorising the approval of direct criminal norms ${ }^{43}$. And according to RosARIA SicURELLA, this gap could not be filled by the vague formula adopted in article 325 TFEU ${ }^{44}$.

suspension, refer the draft back to the Council for adoption. Within the same timeframe, in case of disagreement, and if at least nine Member States wish to establish enhanced cooperation on the basis of the draft regulation concerned, they shall notify the European Parliament, the Council and the Commission accordingly. In such a case, the authorisation to proceed with enhanced cooperation referred to in Article 20(2) of the Treaty on European Union and Article 329(1) of this Treaty shall be deemed to be granted and the provisions on enhanced cooperation shall apply.

2. The European Public Prosecutor's Office shall be responsible for investigating, prosecuting and bringing to judgment, where appropriate in liaison with Europol, the perpetrators of, and accomplices in, offences against the Union's financial interests, as determined by the regulation provided for in paragraph 1 . It shall exercise the functions of prosecutor in the competent courts of the Member States in relation to such offences.

3 . The regulations referred to in paragraph 1 shall determine the general rules applicable to the European Public Prosecutor's Office, the conditions governing the performance of its functions, the rules of procedure applicable to its activities, as well as those governing the admissibility of evidence, and the rules applicable to the judicial review of procedural measures taken by it in the performance of its functions.

4. The European Council may, at the same time or subsequently, adopt a decision amending paragraph 1 in order to extend the powers of the European Public Prosecutor's Office to include serious crime having a cross-border dimension and amending accordingly paragraph 2 as regards the perpetrators of, and accomplices in, serious crimes affecting more than one Member State. The European Council shall act unanimously after obtaining the consent of the European Parliament and after consulting the Commission».

42 H. SAtzger, International and European Criminal Law, Hart Publishing, Oxford, 2012, p. 74 s.

43 G. GRasso, Il Trattato di Lisbona e le nuove competenze penali dell'Unione Europea, in Studi in onore di Mario Romano, Jovene, Napoli, 2011, p. 2347 s.

44 R. Sicurella, Il diritto applicabile dalla Procura europea: diritto penale 
The lawmakers preferred article 83.2. TFEU.

As a result, the approximation of criminal laws and regulations of the Member States is undoubtedly less strong than the one allowed by article 325 (and, of course, article 86) TFEU.

The European Union is fully interested in the protection of fundamental rights. From this point of view, one could cite: the recital (28) ${ }^{45}$ of the Preamble, where some safeguards - also recognised by the Charter of the Fundamental Rights of the European Union - are enshrined; and the recital (21) ${ }^{46}$ that concerns the principle of ne bis in idem with regard to cases of cross-border crime ${ }^{47}$.

The protection of the Union's financial interests "concerns not only the management of budget appropriations, but extends to all measures which negatively affect or which threaten to negatively affect its assets and those of

sovranazionale o diritto nazionale 'armonizzato'? Le questioni in gioco, in Diritto Penale Contemporaneo, 17.12.2013.

45 Recital (28) of the Directive EU/1371/2017: « The intended dissuasive effect of the application of criminal law sanctions requires particular caution with regard to fundamental rights. This Directive respects fundamental rights and observes the principles recognised in particular by the Charter of Fundamental Rights of the European Union (the 'Charter') and in particular the right to liberty and security, the protection of personal data, the freedom to choose an occupation and right to engage in work, the freedom to conduct a business, the right to property, the right to an effective remedy and to a fair trial, the presumption of innocence and the right of defence, the principles of the legality and proportionality of criminal offences and sanctions, as well as the principle of ne bis in idem. This Directive seeks to ensure full respect for those rights and principles and must be implemented accordingly».

46 Recital (21) of the Directive EU/1371/2017: « Given the possibility of multiple jurisdictions for cross-border criminal offences falling under the scope of this Directive, the Member States should ensure that the principle of ne bis in idem is respected in full in the application of national law transposing this Directive».

47 E. BAsIle, Brevi note sulla nuova direttiva PIF, in Diritto Penale Contemporaneo, 12/2017, p. 66. 
the Member States, to the extent that those measures are of relevance to Union policies» ${ }^{48}$.

Pursuant to article 3 of the Directive, «the following shall be regarded as fraud affecting the Union's financial interests:

(a) in respect of non-procurement-related expenditure, any act or omission relating to:

$i$ the use or presentation of false, incorrect or incomplete statements or documents, which has as its effect the misappropriation or wrongful retention of funds or assets from the Union budget or budgets managed by the Union, or on its behalf; ii non-disclosure of information in violation of a specific obligation, with the same effect; or iii the misapplication of such funds or assets for purposes other than those for which they were originally granted;

(b) in respect of procurement-related expenditure, at least when committed in order to make an unlawful gain for the perpetrator or another by causing a loss to the Union's financial interests, any act or omission relating to:

i the use or presentation of false, incorrect or incomplete statements or documents, which has as its effect the misappropriation or wrongful retention of funds or assets from the Union budget or budgets managed by the Union, or on its behalf; ii non-disclosure of information in violation of a specific obligation, with the same effect; or iii the misapplication of such funds or assets for purposes other than those for which they were

48 Recital (1) of the Directive EU/1371/2017. 
originally granted, which damages the Union's financial interests;

(c) in respect of revenue other than revenue arising from VAT own resources referred to in point (d), any act or omission relating to:

i the use or presentation of false, incorrect or incomplete statements or documents, which has as its effect the illegal diminution of the resources of the Union budget or budgets managed by the Union, or on its behalf;

ii non-disclosure of information in violation of a specific obligation, with the same effect; or iii misapplication of a legally obtained benefit, with the same effect;

(d) in respect of revenue arising from VAT own resources, any act or omission committed in crossborder fraudulent schemes in relation to:

$i$ the use or presentation of false, incorrect or incomplete VAT-related statements or documents, which has as an effect the diminution of the resources of the Union budget;

ii non-disclosure of VAT-related information in violation of a specific obligation, with the same effect; or

iii the presentation of correct VAT-related statements for the purposes of fraudulently disguising the non-payment or wrongful creation of rights to VAT refunds».

However, the scope of the Directive is broader than the one corresponding to the conduct of fraud in the strict sense. In other words, given the aim of the Directive (i.e. the protection of the Union's financial interest), the lawmakers did have regard to the wider context of the lawful economy, 
taking into account the effect of some criminal conducts: first, on the EU internal market; and second, on the European citizens' confidence in the EU Institutions ${ }^{49}$.

As a matter of fact, the aim of protecting the Union's financial interest is also pursued by means of the punishment of other criminal offences, pursuant to article 4 . Among these ones, there is the crime of corruption, whose definition, for the purposes of the Directive, does not coincide with the one provided for by the Italian anti-corruption legislation (see § 2).

In the light of article 4.2.a), «' passive corruption' means the action of a public official who, directly or through an intermediary, requests or receives advantages of any kind, for himself or for a third party, or accepts a promise of such an advantage, to act or to refrain from acting in accordance with his duty or in the exercise of his functions in a way which damages or is likely to damage the Union's financial interests».

Also, in the light of article 4.2.b), "'active corruption' means the action of a person who promises, offers or gives, directly or through an intermediary, an advantage of any kind to a public official for himself or for a third party for him to act or to refrain from acting in accordance with his duty or in the exercise of his functions in a way which damages or is likely to damage the Union's financial interests». With regard to the aforementioned conducts, the definition of public official is relevant. Pursuant to article 4.4, public official means: a) «a Union official or a national official, including any national official of another Member State and any national official of a third country $[\ldots] »$; or b) «any other

49 N. PARISI, Chiari e scuri nella direttiva relativa alla lotta contro la frode che lede gli interessi finanziari dell'Unione, in Giurisprudenza Penale Web, 2017, 8, p. 9. 
person assigned and exercising a public service function involving the management of or decisions concerning the Union's financial interests in Member States or third countries».

\section{Conclusion}

Given the description of how the Italian (and EU) law deals with the crime of corruption, some final consideration can be made.

The reaction of a law system to corruption must consist in: a) punishing those offences that already occurred; but also $b$ ) preventing the crime that could occur in the future.

In order for the aforementioned goals to be achieved, the use of the criminal law-tools is not sufficient. As a matter of fact, criminal law is the most invasive instrument with regard to personal freedoms; thus, it can be used as the last resort, in the light of the subsidiarity principle. Rather, the development of the administrative law-tools would be appropriate.

Furthermore, the so-called corporate crime should be taken into account.

Finally, one should take into consideration the fact that, nowadays, the crime of corruption is characterised by an increasingly relevant supranational and international element. Therefore, the choice - made by the various national lawmakers - to cooperate in the prevention and punishment of those conducts that are criminologically alarming is appreciable. 


\section{Bibliography}

Antolisei F., Manuale di diritto penale. Parte speciale II, Giuffrè, Milano, 2016, p. 405.

BAsILE E., Brevi note sulla nuova direttiva PIF, in Diritto Penale Contemporaneo, 12/2017, p. 66.

BRICOLA F., Tutela penale della pubblica amministrazione e principi costituzionali, in Temi, 1968, p. 141.

Fiandaca G., Musco E., Diritto Penale. Parte speciale. Volume 1, Zanichelli, Bologna, 2012, p. 208.

Grasso G., Il Trattato di Lisbona e le nuove competenze penali dell'Unione Europea, in Studi in onore di Mario Romano, Jovene, Napoli, 2011, p. 2347 s.

Grasso G., Introduzione: Diritto penale ed integrazione europea, in Grasso G., Sicurella R. (edited by), Lezioni di diritto penale europeo, Giuffrè, Milano, 2007, p. 6).

Masullo M. N., I delitti di concussione e di induzione indebita a dare o promettere utilità, in Fiore S., AMARELLI G. (edited by), I delitti dei pubblici ufficiali contro la pubblica amministrazione, Utet, Milano, 2018, p. 91.

PARISI N., Chiari e scuri nella direttiva relativa alla lotta contro la frode che lede gli interessi finanziari dell'Unione, in Giurisprudenza Penale Web, 2017, 8, p. 9.

Satzger H., International and European Criminal Law, Hart Publishing, Oxford, 2012, p. 74 s.

Sicurella R., Il diritto applicabile dalla Procura europea: diritto penale sovranazionale o diritto nazionale 'armonizzato'? Le questioni in gioco, in Diritto Penale Contemporaneo, 17.12.2013. 


\section{Jurisprudence}

Corte Suprema di Cassazione, Sezione IV, judgement $n$. 3251 (3.12.2012).

Corte Suprema di Cassazione, Sezione IV, judgement n. 8695 (4.12.2012).

Corte Suprema di Cassazione, Sezione IV, judgement n. 11754 (11.2.2013).

Corte Suprema di Cassazione, Sezioni Unite, judgement $\mathrm{n}$. 12228 (24.10.2014).

Recebido em 11/09/2019

Aprovado em 01/10/2019

Federico C. La Vattiata

E-mail: federico.lavattiata@unitn.it 
